\title{
Rationalisation of European occupational pensions - A company's perspective
}

Received (in revised form): 10th September, 1999

\section{Gary Hibbard}

is responsible for the operation and management of BP Amoco's international pension and related benefit arrangements. An actuary by profession, this paper is written in a personal capacity, although it draws on work and experiences within the BP Amoco Group. The author hopes the personal views expressed will stimulate debate in this socially important field.

\begin{abstract}
The design and provision of pensions worldwide are going through fundamental change. Whether that change is right or wrong is not the issue - it is happening. The introduction of the EURO, with its implications for participating countries' fiscal management, is a catalyst for change across continental Europe, whose governments and social institutions have been relatively slow to innovate in the area of pensions and related benefits. In this paper, the author takes a holistic view as to how employers will provide for employees' future retirement needs; in particular, whether the classical concept of a pension, namely an income provided in retirement, will continue to take centre stage. The four principal building-blocks of a benefits industry - the interaction with State provision, cost, design and delivery - are considered from the perspective of the employer who must consider its duties to both its staff and its shareholders.
\end{abstract}

Keywords: funding; financial security; benefit design; pan-European funds; risk management; taxation

Gary Hibbard

(BP Pensions Services Ltd, Britannic House, 1 Finsbury Clrcus, London EC2M 2BA.

Tel: 0207496 5230; Fax: 0207496 5616; e-mail: hibbardg@bp.com)

\section{Pensions in Europe today}

The concept of an occupational pension, as we know it in Britain, is widely shared across Europe. The detail of the governance, design and financing is, however, very different across borders. This is not to say that any one system is better than another: each has to be considered in context. Cultural and historical factors can be strong, but should not in themselves be a deterrent to cross-border rationalisation. They do, however, influence the pace of change. But social and fiscal (tax) legislation are the primary drivers behind the development of European employee benefits. To put it simply, each country has built up its retirement/long-term savings industry around its own laws having regard to its own drivers, finances and social pressures. The relative dominance of termination indemnities in Greece and Italy and employees' preference for retirement lump sums over pensions in Belgium are good examples.

With kind permission of William $M$. Mercer, Table 1 demonstrates that occupational provision is inextricably linked with both the form and level of State benefits, both in terms of the 
Table 1 Comparative labour costs in the EU

\begin{tabular}{|c|c|c|c|c|c|}
\hline & $\begin{array}{l}\text { Pay } \\
\text { (based on national } \\
\text { average earnings) }\end{array}$ & $\begin{array}{l}\text { Social } \\
\text { security and } \\
\text { mandatory } \\
\text { benefits }\end{array}$ & $\begin{array}{l}\text { Voluntary } \\
\text { benefits }\end{array}$ & $\begin{array}{l}\text { Total } \\
\text { benefits } \\
\text { cost }\end{array}$ & \multirow[t]{2}{*}{$\begin{array}{l}\text { Total } \\
\text { package } \\
\text { cost }\end{array}$} \\
\hline & & \multicolumn{3}{|l|}{ As a \% pay } & \\
\hline Belgium & 29,520 & 36 & 5 & 41 & 41,553 \\
\hline Denmark & 36,191 & 4 & 3 & 7 & 38,857 \\
\hline Sweden & 27,386 & 39 & 0 & 39 & 38,136 \\
\hline Germany & 29,788 & 22 & 5 & 27 & 37,846 \\
\hline Austria & 29,932 & 23 & 2 & 25 & 37,395 \\
\hline Luxembourg & 30,953 & 14 & 2 & 16 & 35,803 \\
\hline France & 24,666 & 42 & 2 & 44 & 35,453 \\
\hline UK & 29,771 & 7 & 12 & 19 & 35,439 \\
\hline The Netherlands & 28,250 & 13 & 8 & 21 & 34,128 \\
\hline Finland & 25,800 & 28 & 1 & 29 & 33,188 \\
\hline Ireland & 22,805 & 12 & 12 & 24 & 28,278 \\
\hline Italy & 18,296 & 53 & 1 & 54 & 28,125 \\
\hline Spain & 17,536 & 33 & 2 & 35 & 23,638 \\
\hline Greece & 13,945 & 37 & 0 & 37 & 19,080 \\
\hline Portugal & 8,502 & 32 & 1 & 33 & 11,298 \\
\hline USA & 26,634 & 10 & 14 & 24 & 33,052 \\
\hline Japan & 41,299 & 13 & 10 & 23 & 50,815 \\
\hline
\end{tabular}

All figures in EURO.

Source: William M. Mercer - International Benefit Guidelines 1999.

impact on total employment costs, and the need for top-up provision. Clear themes can be drawn. First, European social security (including mandatory) charges form a higher proportion of employment costs than 'voluntary' employer costs. This is expected to continue, although the level of State benefit provided is expected to fall relative to average earnings if not in real terms. From the employer's perspective, social security is expected to become less 'efficient'. Secondly, it is the economies of the Mediterranean countries which are most exposed to this Pay As You Go income/outgo disparity, although competitiveness is currently maintained through average earnings levels below those of northern Europe. Thirdly, Britain and Denmark, which have both been through fundamental reform, stand out as being particularly low social charge countries. ${ }^{1}$

Looking forward, high State benefits and high taxes seems untenable. Either benefits must fall, or taxes must rise.
Either is politically very difficult; transition will take a generation. The longer a government puts off the difficult decisions, the weaker that country's currency and the competitiveness of its industry in the global marketplace. The position was well summarised recently in a joint paper by Tony Blair and Gerhard Schroeder on the 'third way' in Europe:

'Achieving social justice became identified with ever higher levels of public spending regardless of what they achieved or the impact on taxes required to fund it or on competitiveness and unemployment.'

\section{Funding and surplus}

There has been gradual acceptance among European governments that occupational provision should be (pre)funded. Portugal led the second wave of countries to set deadlines by which employers must cover retirement obligations by (ringfenced) external assets. Politically, France and Germany remain 
to carry out fundamental reform aimed at funding: progress will be slow because of the scale of the required cashflow calls on employers in Europe's two largest European economies. ${ }^{2}$

Funding provides a sensible financial discipline on employers. Although international accounting standards are designed to recognise the cost of employee benefits as it accrues, ie, spread uniformly through $\mathrm{P} \& \mathrm{~L}$ over the employee's career, in an unfunded plan the cashflow effect is pushed out into the future. Funding brings the cashflow impact forward so providing greater security for employees, and financial clarity for shareholders, whether DB or DC provision. However, the debate becomes more complex when the State goes on to define the level of funding in DB plans. The UK was not, of course, the first country to introduce a Minimum Funding Requirement (MFR); Portugal, Spain, the Netherlands, Belgium and Ireland preceded it. Continental MFRs are based around insurance company reserving requirements. The primary objective of an insurance company is to maintain its solvency, ie, to demonstrate that it can meet its promises to its policyholders. By contrast, the UK MFR is based on actuarial concepts giving rise to funding levels below true solvency in the current low interest rate environment. The UK MFR anticipates higher returns from equities over bonds. It also makes no allowance for discretionary benefits, even where there is an established practice of such (compare the management of insured products where regard is taken to policyholders' reasonable expectations).

In principle, pension scheme funding is straightforward. The employer has a duty to maintain solvency (ie, sufficient funds to meet benefits on discontinuance measured by bond yields/buy-out rates). Surplus over and above solvency is for the employer's account - it represents pre-funding and/or the shareholders' reward for underwriting the DB plan risks. Solvency is the measure of true 'surplus', and it is market related.

Trustees should look to solvency. The MFR confuses the true picture, and dangerously so - many UK schemes are technically insolvent today. The UK would do well to follow the continental model second time round.

It seems that the UK adopted a weaker financial regime for pension funds compared to insurers because of an incorrect but commercially appealing theory. Anglo-Saxon management has sought to reduce long-term cost by investing in equities, while simultaneously looking to reduce short-term P\&L and cashflow strain on their companies by funding below true solvency. Increased risk is the glue that holds this paradigm together. If the risks do not pay off, management has a major reputation issue to address to its scheme's members and its shareholders: hardly an outcome that forward-looking companies should be contemplating. Although empirical data in developed markets support the belief that equities outperform bonds, this is not necessarily true in the short term. But solvency is concerned with the short term: there is little comfort in knowing that a scheme was expected to be financially sound in the long term, if the scheme has been found to be insolvent on winding up. From the shareholder's perspective, not paying in contributions when a scheme falls below true solvency increases the likelihood of a higher P\&L hit and/or cashcall in the future. The share price of the sponsoring company should reflect the increased volatility. That it often does not suggests that analysts' focus is short term, exacerbated by those accounting conventions (eg, UK) that mix cost and risk. 


\section{Funding - State provision}

Is it appropriate to look to European States also to (pre)fund their obligations to their citizens? ${ }^{3}$ Developing economies such as those in Central and Eastern Europe moved to funded State pensions to boost their capital markets, with the pension assets importantly being (largely) ringfenced within the country. ${ }^{4}$ The same drivers may not apply to already developed markets with free capital movements. Indeed, could European markets assume regular, large flows of social security cash looking for a home without artificially boosting prices (and so depressing future return expectations)? Some commentators believe that new money is already underpinning market highs to some extent. The author cannot but help feel, for example, that the Stakeholder Pensions debate in the UK is moving along the wrong lines, and that the success of the UK occupational pensions market could be damaged in the process.

\section{Flexibility in the remuneration package}

Unsurprisingly, Table 1 demonstrates that occupational provision is highest where State provision is lowest. Pensions are but one element of the total remuneration package, the cost of provision for which competes with salary and other benefits. BP Amoco looks to shareholder value which means regard not just to competitive labour market practices within the relevant industry/comparator group, but also to the discipline of total employment costs. By way of example, rising pension costs would either have to be met from demonstrable increased productivity (relative to our competitors), or by reductions elsewhere in the package, or by our shareholders.

Defined benefit pensions models are increasing in cost as people live longer. Low interest rates have also added to cost, as current annuity buyout rates testify. ${ }^{5}$ If an employer can pass more value to its employees for the same cost through other means then, other things being equal, the more efficient route is in both shareholders' and employees' interests. Other means could include a move to DC or other long-term savings plans, lump sum/termination indemnity plans or share plans taking a greater role in the total remuneration package.

Within BP Amoco, all such options are given careful consideration. They are all means of providing financial security to employees in their retirement. Which is the more appropriate in a given environment depends on the cultural, legislative and fiscal factors noted at the beginning of this paper. (As a generalisation, 'pensions' lock in employees' capital for longer which is the primary reason why 'pensions' often attract favourable (ie, deferred) taxation. In theory, DB plans should stand well they provide a form of financial security that employees cannot replicate themselves through private savings. In practice, DB is not well communicated (and therefore appreciated). Indeed, often the only time that an employer runs a major communication programme, it is to persuade staff to move to DC! Over-regulation (relative to other occupational benefits) does not help. Phased drawdown of AVCs in the UK is a good example of a well-meaning concept intended to provide flexibility (and hence value) to those retirees who desire it, but which in practice is in danger of being smothered by regulatory detail.

Providing employees with meaningful flexibility is undoubtedly the most efficient way to add value. Many Danish employers adopt a total remuneration approach, providing extra salary from 
which employees elect their own level of pension contribution (hence the relatively high pay, low benefits equation in Table 1 ). One of the reasons why Provident Funds have proved so popular outside Europe is that such vehicles combine retirement savings with other benefits (eg, medicare, housing and other loans out of accrued capital). 401k plans permit 'hardship' loans, but increasingly $401 \mathrm{k}$ often seems to double as a very efficient share plan — with many employees holding upwards of 25 per cent of their employer's shares in their 401k pots. Although DC/savings arguably provides a simpler framework than DB to transit to total remuneration, it is by no means the only option for large employers. For example, BP Amoco operates a final salary pension scheme in the UK with six contributory levels ( 0 per cent to 15 per cent) providing flexible accrual rates (60ths to 35ths).

Post-retirement medical provides an interesting parallel. Its cost is also increasing as people live longer, potentially more so than for pensions. In the USA, employers are looking to manage healthcare costs (ie, to continue to bear the financial risks) rather than give up providing the benefit. By contrast, the same employers have been replacing DB pension plans with DC (401k) plans. An interpretation is that the US healthcare culture is stronger than the DB pension culture. Will the same prove true for Europe where the DB pension culture has hitherto been strong?

\section{The emergence of Defined Contribution}

The most developed pension industries in Europe (the Netherlands, UK, Switzerland) have grown around DB systems, particularly final pay-based systems. DC is a relative European newcomer, albeit that it has made a big impact in recent years at the macro level in previously unfunded countries, or those where occupational provision was in its relative infancy (or in the case of Eastern Europe, rebirth), and at the micro level for smaller employers everywhere. However, we should not forget that on a pan-European scale, DC schemes have yet to be experienced over a number of economic cycles. Few European employees have retired under DC systems: perhaps surprisingly, this is also true of the US $401 \mathrm{k}$ industry. ${ }^{6}$

The author is a supporter of (occupational) retirement provision in general. DB is not black, nor DC white. Each targets different objectives, with differing contribution requirements, from which shareholders and social partners should make their decisions accordingly. Importantly, DC implies a new employer-employee relationship for European employers. The solidarity principle does not apply in that the benefit can change markedly for two otherwise similar employees retiring at different times. The employer's primary duty switches from underwriting financial risk to providing the tools to allow staff to identify and manage those risks themselves, ie, from financial to reputational risk. ${ }^{7}$ The tools (including meaningful investment choice) which have been developed in the USA have, to a large extent, yet to be replicated in Europe due to investment restrictions and the relative underdevelopment of our pensions/savings industry. Neither this nor the solidarity principle has proved an issue to date because the long-running bull market has produced consistently 'good news' for retirees. Additionally, it can be expected that contributions which differ by age will be impacted by ageism concerns, as has happened in Australasia.

What matters in a DC scheme is the 
rate of contribution. DC plans are mistakenly seen by some employers as a lower-cost alternative to DB. DC should be a lower-risk but higher-cost alternative: contributions to a 'comparable' DC plan should be higher, as the average employee (who cannot spread risk across the workforce) is likely to be more risk averse in choice of investments. (Administration costs tend to be higher too. Tax differentials aside, the advantage that the employer provides in a DC plan over personal savings vehicles is in utilising its buying power to the benefit of its employees.) Employers recognise this cost-risk equation, ${ }^{8}$ yet DC rates are often lower than declared DB costs (compensation having not obviously been provided elsewhere in the package). Reflecting the earlier discussion on solvency, perhaps employers are correcting for what they believed their DB plans costed. However, if investments do not perform, employers may need to revisit the fundamentals ultimately you receive in benefits what you pay for in contributions.

DC is argued to be more equitable in a world where labour is more mobile than previously (though other forms of DB scheme, eg, revalued career average or cash balance, address the equity argument perfectly well, particularly in a low-inflation environment). Although the current generation of management and professional employees are perhaps more mobile than previously, there is little evidence, nor underlying logic, to suggest that the bulk of the labour force is more mobile - the social bonds of family, friends and schooling remain strong. ${ }^{9}$ Indeed, how many businesses could maintain profitability if there were a quantum leap in turnover? How many have planned for such?

In conclusion, the drivers for DC are neither logically nor commercially overpowering but they have been timely as the wider globalisation and funding debates have emerged. Looking forward, the drivers may well be different.

\section{Pan-European solutions}

It is counter-intuitive to look to country-level solutions while the focus is increasingly becoming pan-European. Many employers do business across Europe. These businesses do not operate as mutually independent units; they seek competitive advantage by sharing organisational resources across borders, wherever possible. This is certainly the case in BP Amoco, since energy is an international product. Why not bring some of the day-to-day business procurement strategies into employee benefits, particularly in Europe which, because of its history, is much fragmented and puts European companies at a relative disadvantage to their US counterparts, for example?

Of course, this is done already with multinational pooling. But so much more could be done. BP Amoco operates a preferred provider programme whereby local management select actuarial, consultancy and administration services from three international providers, combining local excellence with the support and coordination skills of a global network. It is also in the final stages of extending the preferred provider system to European investments to achieve a consistent high-grade product, improved understanding and economies of scale. Country-level investment solutions made sense in a world of separate investment restrictions and currencies. The Commission's drive to adopt the prudent man principle across Europe is greatly to be welcomed.

The most significant area where value can be added, however, is at the heart of the matter, ie, the legal vehicle which delivers the benefits. If all employee 
benefits could be provided through one legal vehicle (a pan-European scheme), cost (external fees, and internal management time) would be much reduced. Furthermore, it is easier to manage surplus/deficit issues in one large fund than in a series of smaller separate legal vehicles. This is, after all, the principle by which insurers (or pooling in general) works. Employees directly benefit in that resources can be applied more effectively, eg, investment choice in DC schemes can be applied to the smaller as well as the larger employing countries. It is difficult to find meaningful downside in a pan-European scheme: possibilities might include the general hassle of converting from local to regional structures, and the risk that social partners would look to create pan-European benefit structures.

Regarding the latter, although the European Trade Union Confederation has made noises in this direction recently, benefits harmonisation remains unlikely until there is harmonisation of social security benefits.

\section{A way forward}

Employers are always looking to control (including shedding) risk, whether that risk relates to their core business or their employees. If social partners continue to favour the asymmetric argument that 'surplus' is for the benefit of plan members but that employers should make up deficits, then this is a clear signal to employers to move to DC.

Surrendering your capital for an annuity is a very unattractive option in a low-interest-rate environment. The solution is deceptively simple, though uncomfortable for the traditionalist: either allow phased retirement (as is permitted with UK personal pension plans) or, better still, convert to lump sum or savings plans and let employees decide whether they wish then to buy an annuity. It is questionable whether annuities add value. For example, after many years of pressure from the UK pensions industry, the concept of a 'fixed' retirement date seems to be weakening in that the British Government has recently announced changes which enable occupational DC schemes, including AVC schemes attached to DB schemes, to benefit from the income drawdown rules that apply to personal pension arrangements.

Post EURO, European governments are budget constrained. Social security charges will need to remain high for some time (to meet current pension outgo) but prospective benefits for future retirees will fall. The author can see (though would not agree with) reputational pressure coming on employers to make good the benefits gap. (Employers with 'delinked' plans will be able to resist for longer, but will not be immune. Perversely, DC plans may be even more exposed on moral grounds to such claims because of the transfer of risk to the employee.) Employers should lobby for certain regulatory barriers to be eliminated, permitting pan-European schemes: the economies of scale will go a little way towards meeting increased baseline costs. Looking at the macroeconomics, rather than receive a stream of income tax when pensions become payable, government could permit benefits to be taken as a lump sum on retirement but charge a differential tax rate on that lump sum. Governments get their tax quicker, and retirees both receive their capital quicker and see a relative tax break. There are examples both within and outside Europe, eg, in Austria (book reserved arrangements only), Belgium and Spain, 'pensions' may be taken as a lump sum or an annuity, but with a differential tax payable on the lump sum. 
The tax-free partial commutation route in the UK, although much prized, seems particularly anomalous by comparison.

Lump-sum plans do not have to be DC of course. Final salary plans treat early leavers and long stayers relatively equitably in a low-inflation environment, but hybrids such as career average schemes are better adapted to such an environment. Interest in hybrids is (re)growing in the Netherlands.

\section{Conclusion}

Overall, the European pensions industry is a great success: millions of people are receiving supplemental pensions through rights built up over their working lives. Occupational pensions fulfil a vital social need. But the industry should not rest on its laurels. Now is the time to ask whether what was best in the past remains optimal for the future.

Pan-European schemes are the way of the future. As with everything in the pensions world, decisions made today can take a generation to yield results. The sooner the transition commences, the better. Saving for retirement will become more important as State provision falls. Indeed, it is difficult to see how Europe can implement fundamental change at the employee and country level, until the bigger European picture evolves including whether 'single purpose' pension funds should evolve into multi-purpose benefit vehicles (eg, Provident Funds). Employees should be given more flexibility as to how their retirement benefits (including medical and other insurances) are provided. Employees can then choose what they want, rather than what the employer thinks they, on average, want. In particular, phased retirement and lump-sum models, whether DB or DC, can provide a win-win scenario for employees, shareholders and the tax man.
These are social, economic and political prizes worth pursuing.

\section{References}

1 The figures flatter in that there is undoubtedly cost leakage elsewhere into the State budget such that social security costs do not in themselves tell the whole story. Britain carried out its reform in the 1980 s both reducing the accrual of future State benefits, and then linking these benefits to prices not earnings. Effective State provision is higher after allowing for means-tested supports, such as housing. Denmark's reforms are increasingly centring on universal means testing.

2 German occupational pensions are not as 'unfunded' as first sight might suggest. Not only is much use made of Pensionskassen, direct insurance and support funds, but pensions debt on one side of the balance sheet is often countered by cash and other liquid investments on the other. Although this cash is not legally ringfenced for pension provision, provided the State is prepared to continue to provide ultimate security through the PSV insolvency insurance system, the author contends that, with the exception of the inadequate Teilwert accounting assumptions, the German system is both well considered and efficient from both the employer's and the employee's perspective. That Germany is looking to new models (particularly tax-advantageous long-term savings plans (aka DC)) is perhaps more a reflection of the desire to modernise their system, externalising balance sheet liabilities in the process.

By contrast, the French system is the weaker. There is no national insolvency protection, nor do accounting rules oblige the majority of employers to record pension obligations on their balance sheets (though disclosure through explanatory notes is common). Legislation has been drafted, and even enacted, aimed at funding but has not progressed further due to a lack of political and social consensus. There has though been widespread interest in top-up insured DC schemes albeit that only low levels of contribution are currently permitted.

3 The author deliberately ducks the question of whether current defined benefit State provision should become defined contribution, focusing instead on the core issue - funding.

4 From the perspective of the State, first, from where will the tax revenues come to enable funding of future promises while paying current pensioners? Not compulsory savings which are in the author's opinion a perceived solution to a different problem. Nor, under the Maastricht criteria, by European governments writing new debt. If the monies are found by disinvestment elsewhere, then at the macroeconomic level where is the added value? Secondly, value is not created through funding per se, but through investment. Under the 'Chilean model', investment restrictions mean that the better proportion of the monies are in fact 'reinvested' back into the State in the form of various bonds: a 
pension promise can be likened to a bond, arguably such 'economic miracles' merely represent an institutionalising of State pension debt. Perhaps, the most viable funding option from a macroeconomic perspective is privately managed infrastructure investment projects?

5 Of course, echoing the discussion about risk in the preceding section, the possibility of a sustained low-interest-rate environment should always have featured in our financial planning. We have been optimistic in the past by assuming historic high rates (absolute and real) of return will continue into the future.

6 Although 401k plans now account for over half of total US retirement funds, it should be remembered that $401 \mathrm{k}$ was introduced in the late 70 s. As a generalisation, $401 \mathrm{k}$ plans are immature (ie, excess of contributions and investment return over benefits outgo), traditional DB plans mature. Over the next 15 years, there will be a significant outflow of funds from $401 \mathrm{k}$ as the US baby boomers retire.

7 DC and involuntary early retirement remains an untested area: the solution could entail a change in employer attitude, moving away from protection (of the retirees income stream) to compensation (eg, lump sum equal to future contributions payable).

$8 \mathrm{Eg}$, see Bacon \& Woodrow's May 1998 survey of FTSE 100 finance directors' views on their pension schemes. 81 per cent of respondents said that they would prefer a 1 per cent increase in pension costs in return for stability of that cost. 41 per cent of respondents would even go as far as accepting a 3 per cent increase in cost for stability! Echoing themes discussed earlier in this paper, interestingly lack of flexibility was the highest-rated current concern (27 per cent) about their pension scheme, more than cost (14 per cent) and the effect of the MFR (16 per cent).

9 Watson Wyatt Worldwide have carried out some thorough and intriguing analysis of US labour force dynamics under the heading of 'Workplace Renewal'. The reader is also referred to the ERISA Industry Committee's July 1996 White Paper (the author understands the NAPF will shortly submit similar analysis on UK labour mobility). Such sources suggest that the perception of increased mobility has been significantly influenced by a generational surplus of baby boomers entering the workforce over the last two decades (as well as by an increase in part-time work, but not necessarily temporary work). This surplus will soon run out suggesting that skill retention will become a more prominent feature in the US labour market with what has been known as structural early retirements phasing down. High-level analysis suggests that Europe is going through a similar generational surplus of younger workers, but with a time lag of five to ten years. 